\title{
SOME SERUM ACTIVITY MARKERS OF AIRWAYS INFLAMMATION IN DIFFICULT-TO-CONTROL ASTHMA PATIENTS
}

\author{
Bohuslav Král*, Jan Krejsek*, Zdena Paráková*, Otakar Kopecký, Doris Vokurková, Václav Derner, Miroslava Toušková \\ *IInd Department of Medicine, Charles University, Faculty of Medicine, Hradec Králové; \\ (Head: prof. MUDr. V. Pidrman, DrSc.) \\ Department of Clinical Immunology and Allergy, University Teaching Hospital, Hradec Králové;
}

(Head: MUDr. O. Kopecký)

\begin{abstract}
Summary: The main aim of the present study was a search for a characteristic serum marker of inflammatory activity in the airways of asthmatics with difficult-to-control disease. Therefore, serum levels of interleukin-4 (IL-4), serum low-affinity Fc Epsilon Receptor II (sFcER II), Interferon-gamma (INF-gamma) Immunoglobulin-E (IgE), Interleukin-2 (IL-2), serum Interleukin Receptor 2 (sIL-2R) and Intercellular Adhesion Molecule-1 (sICAM-1) were measured in 2 groups of asthmatics: 1-26 patients with difficult-to-control asthma (DTCA), 2-22 asthmatics, minimally symptomatic (MSA).

Results: No significant difference in either measured parameters between the DTCA and MSA group in peripheral blood samples was found. Conclusion: The above mentioned serum markers of T- and B-cell activation as well as the serum ICAM-1 level are not sensitive enough to determine the type, activity and severity of the inflammatory process in the asthmatic airways.
\end{abstract}

Key words: Difficult-to-control asthma; Interleukin-4; Interleukin-2; Soluble Fc Epsilon Receptor II; Soluble Interleukin-2 Receptor; Intercellular Adhesion Molecule-1

Abbreviations used in the study

IL - Interleukin

INF - Interferon

TNF - Tumor necrosis factor

IgE - Immunoglobulin E

FcER - Fc epsilon receptor

LT - Leucotrien

PG - Prostaglandin

PAF - Platelet activating factor

Th - T-helper lymphocyte

\author{
APC - Antigen presenting cell \\ GM-CSF - Granulocyte-macrophage colony stimulating \\ factor \\ ICAM - Intercellular adhesion molecule \\ VCAM - Vascular adhesion molecule \\ LFA-1 - Lymphocyte function associated antigen-1 \\ VLA-4 - Very late antigen 4 \\ BAL - Bronchoalveolar lavage \\ BHR - Bronchial hyperreactivity
}

The study was approved by local ethical commitee in April, 1994.

Supported by Grant Agengy, IgA-1960-3.

\section{Introduction}

There has been an increase in the prevalence and the severity of bronchial asthma all/over the world, this fact being true especially for the atopic type of asthma $(20,24,38,41)$. According to the study by Vondra (57), such an increase does exist in the Czech Republic as well. The reasons for such an increase in atopy prevalence are not quite clear. Whilst hereditability forms the basis of the definition of atopy, it is clear that the enviroment must have had a major influence on phenotype $(34,38,48,63)$. Longitudinal cohort studies will be required to establish which of the many possible factors are critical to the development of allergy and subsequent asthma. The ultimate aim shall be to identify avoidable factors and to establish prevention protocols $(61,62)$.

The view of asthma has changed radically over the last decade, due to the development of new molecular-biologic methods and by the ability to study cells and mediators directly via the fiberoptic bronchoscope $(22,53)$. Asthma has been proven to be a chronic inflammatory disorder of the airways. The cellular constituents involve mast cells, eosinophils which are typical of allergic disorders. Major inroads have been made into the immunological mechanisms 
driving the inflammatory response with T.cells taking primacy, and B-cells (via IgE) providing a trigger stimulus involving common allergens. Molecular technology has allowed a myriad of mediators to be identified as contributing to both the acute and chronic aspects of the disease, resulting in bronchial hyperreactivity and smooth muscle contraction too much and too early in response to various „triggers“ (specific - allergens, nonspecific -cold, exercise, smoke) (21).

The pathogenesis of the chronic inflammation of asthma is complex and still only partially understood. Once the inflammation has become established, it appears to be maintained by a tissue - driven response, (41). The aetiology of asthmatic airway inflammation is thought to be the development of a specific immune response in the airways. In allergic asthma, the allergen is captured and processed by antigen - presenting cells (APC) which are dendritic cells in the airways mucosa, other less efficient APCS in the airways include monocytes, epithelial cells, B - lymphocytes and fibroblasts. Following the capture of the antigen, the APC migrate to the regional lymph nodes in the airways, where they present the allergen, in association with the major histocompatibility antigen class II molecules, to lymphocytes.

A characteristic of allergic asthma is the selective development of CD 4+ lymphocytes of the Th 2 - type. This selective development of Th 2 - type lymphocytes in asthma is promoted by Interleukin - 4 (IL-4) and inhibited by IL-12. These allergen - specific lymphocytes enter the circulation and selectively home in to the submucosa and mucosa of the airways. Through the production of various cytokines, these lymphocytes direct the inflammatory reaction into the characteristic airways inflammation of asthma (27). Interleukin -4 appears to be an important cytokine in the development of allergic inflammation, not only because of its role in switching T-helper into Th2 lymphocytes, but because it promotes differentiation of B-lymphocytes to produce $\operatorname{IgE}(31,32)$.

The immunoglobulin isotype switch to IgE is dependent on three cytokines: IL-4, INF-gamma and IL-10. IgE secretion by B-lymphocytes requires an additional T-cell derived signal that is provided by a cognate interaction between Bcells and a membrane structure on the B-lymphocytes termed CD $40(7,43,45,46)$.

The second cytokine that is critically important in the regulation of IgE synthesis is INF-gamma (1). Interferon gamma functions as an inhibitor of allergic responses through its capacity to inhibit the effects of IL-4 on B-cells. $\mathrm{IgE}$ production in atopy represents a combination of excessive IL-4 production occuring in the relative absence of Interferon - gamma $(28,39)$.

Interleukin-10 is produced by IL-4 producing T-cells and inhibits the synthesis of INF-gamma by other T-lymphocytes.

In contrast to the Th2-subtype of lymphocyte, Th 1-cells differentiate in the presence of a different range of antigens associated with the delayed type hypersensitivity response. Th 1 cells generate predominantly Interferon-gamma (INFgamma), IL-2 and TNF-beta $(12,13,15,16)$.

The production of cytokines by Th-lymphocyte subtypes is shown in Table 1.

A summary of cytokine actions in allergies is presented in Table 2.

Table 1: Different types of cytokines produced by Th1 and Th2 - cells are described (according to Borish, 1992).

\begin{tabular}{|l|l|l|}
\hline Type 1 helper cells & Type 2 helper cells & Both \\
\hline Interferon gamma & Interleukin- 4 & GM-CSF \\
Interleukin 2 & Interleukin- 5 & Interleukin-3 \\
Tumor necrosis & Interleukin- 6 & \\
factor-beta & Interleukin-10 & \\
& Interleukin-13 & \\
\hline
\end{tabular}

Table 2: In this Table main events dealing with the allergic airway inflammation, diffent cytokines involved and their activity are enumerated (according to Borish, 1992).

\begin{tabular}{|c|c|c|}
\hline & cytokine & activity \\
\hline \multirow[t]{4}{*}{ IgE regulation } & IL-4 & IgE isotype switch \\
\hline & IL-2, IL-5, IL-6 & synergize with IL-4 \\
\hline & interferon gamma & inhibits IL-4 \\
\hline & IL-10 & $\begin{array}{l}\text { inhibits interferon- } \\
\text { gamma }\end{array}$ \\
\hline Eosinophilia & IL-3, IL-5, GM-CSF & eosinophilopoietins \\
\hline \multirow{2}{*}{$\begin{array}{l}\text { Mast cell } \\
\text { development } \\
\text { and activation }\end{array}$} & IL-3, IL-9, IL-10 & \multirow{2}{*}{$\begin{array}{l}\text { mast cell growth } \\
\text { factors }\end{array}$} \\
\hline & $\begin{array}{l}\text { hematopoietic stem } \\
\text { cell factor } \\
\text { connective tissue } \\
\text { activating peptide } \\
\text { (CTAP) }\end{array}$ & \\
\hline \multirow[t]{3}{*}{ Inflammation } & $\begin{array}{l}\text { INF-gamma, GM-CSF, } \\
\text { TNFs, IL-1, IL-4, } \\
\text { IL-6, IL-8 }\end{array}$ & $\begin{array}{l}\text { neutrophil-activating } \\
\text { factors }\end{array}$ \\
\hline & $\begin{array}{l}\text { GM-CSF, TNFs, IL-1, } \\
\text { IL-3, IL-5 }\end{array}$ & $\begin{array}{l}\text { eosinophil-activating } \\
\text { factors }\end{array}$ \\
\hline & $\begin{array}{l}\text { INF-gamma, GM-CSF, } \\
\text { macrophage-CSF, } \\
\text { TNFs, IL-1, IL-2, } \\
\text { IL-3, IL-4 }\end{array}$ & $\begin{array}{l}\text { macrophage-activating } \\
\text { factors }\end{array}$ \\
\hline
\end{tabular}

Either locally produced or circulating IgE antibodies bind to high-affinity IgE receptors (FcERI) on mast cells and circulating basophils, and to low-affinity IgE receptors (FcERII) on eosinophils, monocytes, macrophages, lymphocytes, dendritic cells and platelets (Fig. 1) Cross-linking of the IgE receptors by allergen on the surface of these cells leads to their activation, and the release of various preformed and newly formed mediators in the intercellular spaces 
of the airways. The attraction, activation and prolonged survival of eosinophils in the airway submucosa and mucosa are caused by the production and secretion of IL-3, Granulocyte - Macrophage Colony-Stimulating factof (GMCSF), IL-5, RANTES and Tumour Necrosis Factor - alfa (TNF-alfa) $(15,16,17,18,19,55)$.

Figure 1: Illustrates schematic pathophysiologic patterns of allergic mucosal inflammation and its consequences in the airways of asthmatics (see text for further details).

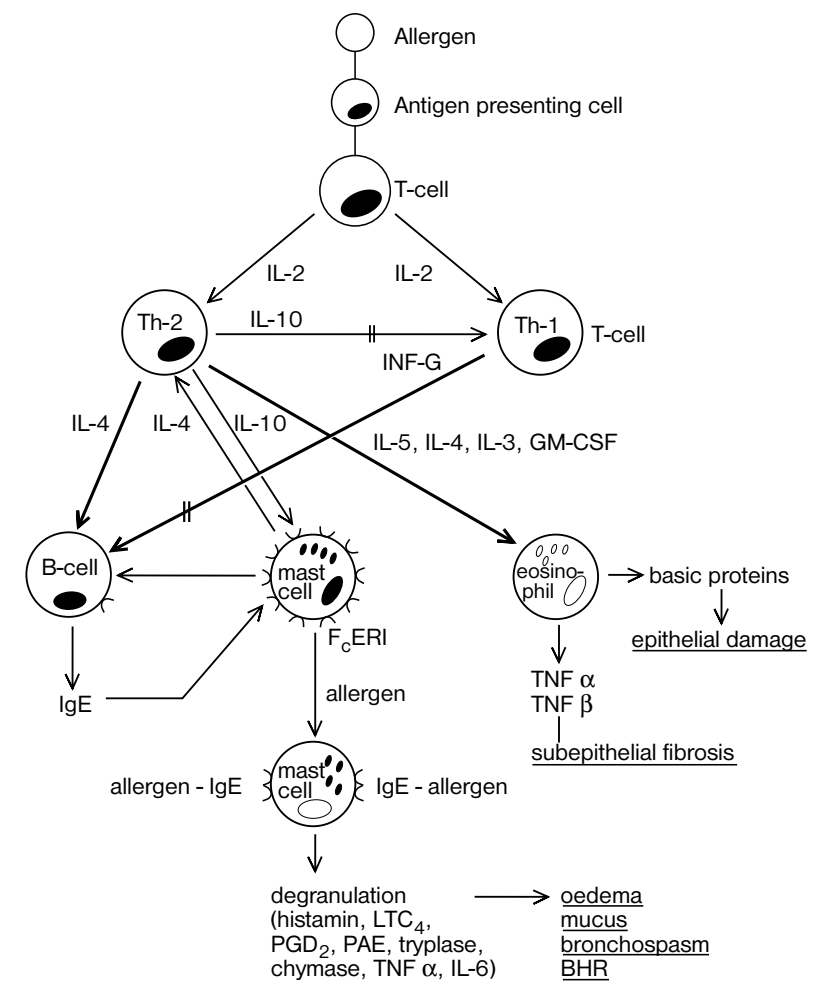

The movement of circulating eosinophils and other inflammatory cells into the airways is controled by „priming“ of the cells by cytokines, local production of chemokinetic and chemmotactic factors, and expression of adhesion molecules on inflammatory cells, endothelium and extracellular matrix (ICAMs, VCAMs, LFA-I, VLA-4) (7,9,23,29, 54,56).

The relative roles of the different adhesion molecules in the development of airway inflammation are not known. Monoclonal antibodies to Intercellular Adhesion Molecule -1 (ICAM-1), Lymphocyte Function Antigen -1 (LFA-1) and Very Late Activation -4 (VLA-4) molecules have been shown to inhibit the influx of eosinophils in the airways following allergen challenge $(37,58)$.

An important characteristic of the chronic airway inflammation of asthma is that constitutional and secondary inflammatory cells may be involved in the maintenance of the chronic inflammation. It appears that the production of pro-inflammatory cytokines by sensitized lymphocytes, but also the expanded involvement of mast cells, eosinophils, constitutive cells, such as epithelial and endothlial cells, and fibroblasts, all apparently play a role in the maintenance of chronic inflammation that characterizes asthma $(41,44)$.

The above-mentioned findings of chronic inflammatory changes in the airway mucosa even in mild forms of asthmatic patients, has led to a change in therapeutic strategy (3). The inhibitory effects of corticosteroids on cytokine production, on cellular responses to cytokines, such as expression of adhesion molecules, increased survival of inflammatory cells and enhanced release of mast cell mediators, now provide a scientific basis for the early use of corticosteroids as a first-line measure in the treatment of asthma $(2,4)$. Furthermore, the effects of corticosteroids on the synthesis of arachidonic acid metabolites are wellknown. With this change in the management strategy, a decline in morbidity and mortality associated with asthma has been proven $(20,24,41)$. Despite these fundamental changes in the management of asthma, some asthmatics still remain „difficult - to - control“ (DTC). (25).

Multiple reasons for the failure of modern treatment strategy in these patients can be identified: 1) non-compliance with treatment, 2) failure to adhere to indicated preventive measures (smoking, exposure to allergens), 3) concommitant disorders (sinusitis, nasal polyps gastro-oesophageal reflux, bronchitis, left ventricular failure, psychogenic factors), 4) inherently severe asthma from the beginning of the disease.

The investigation of the latest category of severe asthmatics represents the main topic of the present study.

\section{Aims of the study}

1) To measure the serum level of IL-4, INF-gamma, the soluble form of the low-affimty receptor on B-lymphocytes (sFcER II/CD-23) and of IgE in patients with difficult to- control asthma (DTCA), as well as in a group of asthma patients with minimal symptomatology (MSA).

2) To examine activation markers of the T-and B-lymphocytes by measuring IL-2, soluble receptor of IL-2 (sIL2R/CD-25), IL-4 and sFcER II (CD-23) in the peripheral blood of both asthmatic groups.

3) To investigate the serum concentration of intercellular adhesion molecule-1 (ICAM-1) as a marker of airway inflammatory activity, in both asthmatic groups.

\section{Study groups}

1) Group of difficult - to - control asthma patients (DTCA) The group was composed of 26 asthmatics in whom daily symptoms were present despite a complex anti-inflammatory and bronchodilatory therapy according to the International Treatment Strategy being instituted. There were 14 women and 12 men in the group, their mean age being 52.1 years (range 24-72 years) and the 
mean disease duration was 19.8 years (range 2-60 years). Atopic asthma was diagnosed in $14(53.8 \%)$ patients, 5 of them suffering from asthma since childhood. Sustained systemic corticoid treatment was necessary in $16(61.5 \%)$ patients.

2) Group of minimally symptomatic asthma patients (MSA) This group consisted of 22 asthmatic subjects, 13 women and 9 men, whose mean age was 50.9 years (range 22-73 years), and who had an average diagnosis of asthma of 15.1 years (range 3 to 55 years). The atopic form of asthma was found in $15(68.1 \%)$ of subjects, it being present since child-hood in 3 of them.

Two patients had no sustained therapy (only occasionally was the rescue bronchodilatory drug necessary). Twenty subjects were on inhaled corticosteroids with a daily dose of $0.2-0,8 \mathrm{mg}$.

The symptom score was classified into 4 grades according to the international consensus: grade 1 being no dyspnoea, no cough, grade 4 representing dyspnoea and cough every day and night for the last year. Similarly, the average daily use of rescue $3-2$ inhalations for the last year, was estimated. The best value of the forced expiratory volume in 1 second (FEV-1\%) and of the forced vital capacity (FVC \%) was measureed following two inhalations of fenoterol $(0.4 \mathrm{mg})$ from a dosier-aerosol device.

\section{Methods}

After obtaining an informed consent, the patients were referred to the immunological laboratory for blood sampling. The patients were asked to abstain from all corticosteroid drugs for a period lasting at least 36 hours. Blood sampling for immunological examination took place in a period of 1 to 2 weeks following clinical and functional investigation.

1. Blood sampling

Peripheral blood was obtained by venepuncture of cubital vein. Blood sample was left at room temperature for 1.5 hours. After centrifugation serum samples were stored at $-70^{\circ} \mathrm{C}$ until measurement. Samples were thawed only once.

2. Determination of the serum level of $\operatorname{IgE}$, cytokines and soluble membrane molecules

Determination was performed by standard immunochemical method using comercially available diagnostic kits according to the instructions of manufacturers. Absorbance was measured by Titertek, Flow, UK spectrofotometer.

Total IgE: Immunotech, Marseille, France

IL-2 level: Quantikinine, RD Systems, Minneapolis, MN, USA

IL-4 level: Quantikinine, RD Systems, Minneapolis, MN, USA Interferon gamma: Endogen, Inc., Cambridge, MA, USA sIL-2R: Immunotech, Marseille, France
sICAM-1: Quantikinine, RD Systems, Minneapolis, MN, USA

sCD23: Immunotech, Marseille, France

\section{Statistical evaluation}

An unpaired T-test for the evaluation of differences between groups was used. In some parameters, the variability analysis with the Bonferroni method was applied. Statistical evaluation was performed using the software package BMDP.

\section{Results}

The clinical characteristics of both investigated groups are depicted in Table 3. No significant difference of age and of the asthma duration between both groups was found, whereas the symptom score, and the number of rescue B-2 inhalations was significantly higher in the DTCA patients.

A significant difference in FVC and FEV 1 values between the study groups was estimated, both values being much lower in the DTCA patients cohort (Table 4).

Table 3: Clinical characteristics of two asthmatic patient groups under investigation are represented.

\begin{tabular}{|l|c|c|c|c|c|}
\hline Group & $\mathrm{N}$ & $\begin{array}{c}\text { Age } \\
\text { (years) }\end{array}$ & $\begin{array}{c}\text { Asthma } \\
\text { duration } \\
\text { (years }\end{array}$ & $\begin{array}{c}\text { Symptom } \\
\text { score } \\
(1-4)\end{array}$ & $\begin{array}{c}\text { Rescue } \\
\text { beta-2 } \\
(\mathrm{N})\end{array}$ \\
\hline $\begin{array}{l}\text { Difficult } \\
\text {-to-control- } \\
\text { asthma }\end{array}$ & 26 & $52.1 \pm 14.0$ & $19.8 \pm 14.8$ & $3.17 \pm 0.50$ & $7.8 \pm 2.9$ \\
\hline $\begin{array}{l}\text { Minimal } \\
\text { symptomatic } \\
\text { asthma }\end{array}$ & 22 & $50.9 \pm 13.9$ & $15.1 \pm 12.6$ & $1.15 \pm 0.32$ & $0.9 \pm 1.1$ \\
\hline $\begin{array}{l}\text { Statistical } \\
\text { significance }\end{array}$ & n.s. & n.s. & $\mathrm{p}<0.001$ & $\mathrm{p}<0.001$ \\
\hline
\end{tabular}

Table 4: This Table describes functional characteristics of both asthmatic groups under study.

\begin{tabular}{|l|c|c|c|}
\hline Group & $\mathrm{N}$ & $\begin{array}{c}\text { Forced vital } \\
\text { capacity } \\
\text { (\% predicted })\end{array}$ & $\begin{array}{c}\text { Forced expiratory } \\
\text { volume in 1 second } \\
\text { (\% predicted })\end{array}$ \\
\hline $\begin{array}{l}\text { Difficult } \\
\text {-to-control } \\
\text { asthma }\end{array}$ & 26 & $79.2 \pm 16.7$ & $59.3 \pm 18.8$ \\
\hline $\begin{array}{l}\text { Minimal } \\
\text { symptomatic } \\
\text { asthma }\end{array}$ & 22 & $92.4 \pm 13.6$ & $72.5 \pm 21.6$ \\
\hline $\begin{array}{l}\text { Statistical } \\
\text { significance }\end{array}$ & $\mathrm{p}<0.005$ & $\mathrm{p}<0.02$ \\
\hline
\end{tabular}

Table 5 demonstrates the serum concentrations of IL-4, INF-gamma, sFcER II and IgE in both asthmatic groups, as 
well as in 20 healthy subjects (blood donors). No significant changes in IL-4 values between both asthmatic groups, as well as between asthmatics and control subjects, was found.

While no significant difference between DTCA and MSA asthmatics in INF-gamma was apparent, its value was significantly higher in both asthmatic cohorts in comparison with healthy poeple.

The same result is true for the sFcER II serum concentrations.

The average serum IgE level is much higher in the DTCA asthma patient group than in the MSA and control subjects, but because of a very high standard deviation in the DTCA group, statistical significance could not be reached. This high standard deviation was caused by an abnormally high $\operatorname{IgE}$ value in one very severe atopic patient, being $7,104 \mathrm{IU} / \mathrm{ml}$.

Table 5: Serum concentrations of interleukin-4 (IL-4), interferon gamma (INF-gamma), serum Fc epsilon receptor II (sFcRII) and immunoglobulin E (IgE) in examined asthmatic groups are described.

\begin{tabular}{|l|c|c|c|c|c|}
\hline Group & $\mathrm{N}$ & $\begin{array}{c}\mathrm{IL}-4 \\
(\mathrm{pg} / \mathrm{ml})\end{array}$ & $\begin{array}{c}\mathrm{INF}-\mathrm{G} \\
(\mathrm{pg} / \mathrm{ml})\end{array}$ & $\begin{array}{c}\text { sFcERII } \\
(\mathrm{pg} / \mathrm{ml})\end{array}$ & $\begin{array}{c}\mathrm{IgE} \\
(\mathrm{IU} / \mathrm{ml})\end{array}$ \\
\hline DTCA 1 & 26 & $14.4 \pm 2,3$ & $4.45 \pm 1.05$ & $4.78 \pm 7.15$ & $473.9 \pm 1374.4$ \\
\hline MSA 2 & 22 & $15.8 \pm 4.1$ & $4.31 \pm 1.10$ & $3.25 \pm 1.57$ & $129.5 \pm 165.2$ \\
\hline Controls 3 & 20 & $16.4 \pm 4.7$ & $3.76 \pm 0.53$ & $1.98 \pm 1.10$ & $122.4 \pm 105.2$ \\
\hline $\begin{array}{l}\text { Statistical } \\
\text { significance }\end{array}$ & n.s. & $\begin{array}{c}1-2 \text { n.s. } \\
2-3 \mathrm{p}<0.01\end{array}$ & $\begin{array}{c}1-2 \text { n.s. } \\
1-3 \mathrm{p}<0.05\end{array}$ & $\begin{array}{c}1-2 \text { n.s. } \\
2-3 \text { n.s. } \\
2-3 \text { n.s. }\end{array}$ \\
\hline
\end{tabular}

DTCA - difficult - to - control asthma; MSA - minimal symptomatic asthma

Table 6 summarizes the results of serum IL-2, sIL$2 \mathrm{R}$ and of ICAM-1 concentrations in three groups under study. No significant differences in IL-2 were noticed between DTCA and MSA patients, as well as in sIL-2R between DTCA, MSA compared with control subjects.

Table 6: This Table presents the results of serum levels of interleukin-2 (IL-2), interleukin-2 receptor (IL-2) and intercellular adhesion molecule-1 (ICAM-1) in different patient groups under study.

Serum levels of IL-2, IL-2 R and ICAM-1 in groups under investigation

\begin{tabular}{|l|c|c|c|c|}
\hline Group & $\mathrm{N}$ & $\begin{array}{c}\text { IL-2 } \\
(\mathrm{pg} / \mathrm{ml})\end{array}$ & $\begin{array}{c}\text { IL-2 R } \\
(\mathrm{pg} / \mathrm{ml})\end{array}$ & $\begin{array}{c}\text { ICAM-1 } \\
(\mathrm{ng} / \mathrm{ml})\end{array}$ \\
\hline DTCA 1 & 26 & $9.91 \pm 0.70$ & $1130.8 \pm 350.9$ & $437.8 \pm 128.3$ \\
\hline MSA 2 & 22 & $9.84 \pm 0.91$ & $1260.9 \pm 564.0$ & $457.2 \pm 190.4$ \\
\hline Controls 3 & 20 & $9.53 \pm 1.11$ & - & $189.0 \pm 42.3$ \\
\hline Statistical & $1-2$ n.s. & $1-2$ n.s. & $1-2$ n.s. \\
Significance & $\begin{array}{l}1-3 \text { n.s. } \\
\text { 2-3 n.s. }\end{array}$ & $\begin{array}{c}1-3 \mathrm{p}<0.001 \\
2-3 \mathrm{p}<0.001\end{array}$ \\
\hline
\end{tabular}

DTCA - Difficult-to-control asthma; MSA - Minimal symptomatic asthma
As far as ICAM-1 concentrations are concerned, a highly significant increase in both asthmatic groups in comparison with healthy subjects was estimated.

When our asthmatic patients were divided into atopic and nonatopic groups without regard to their disease severity, no statistical difference in serum levels of all measured parameters between both groups could be found (Table 7 and 8 ).

Table 7: Serum levels of IL-4, INF-gamma, sFcERII and $\mathrm{IgE}$ in atopic, non-atopic asthmatics and healthy people are illustrated in this Table.

Serum levels of IL-4, INF-gamma, sFc E RII and IgE in atopic and non-atopic asthmatics

\begin{tabular}{|c|c|c|c|c|c|}
\hline Group & $\mathrm{N}$ & $\begin{array}{c}\text { IL-4 } \\
(\mathrm{pg} / \mathrm{ml})\end{array}$ & $\begin{array}{c}\text { INF-gamma } \\
(\mathrm{pg} / \mathrm{ml})\end{array}$ & $\begin{array}{l}\text { sFcERII } \\
(\mathrm{pg} / \mathrm{ml})\end{array}$ & $\begin{array}{c}\mathrm{IgE} \\
(\mathrm{UI} / \mathrm{ml})\end{array}$ \\
\hline Atopics 1 & 29 & $15.1 \pm 4.2$ & $4.14 \pm 0.8$ & $3.79 \pm 2.9$ & $464.6 \pm 1398.7$ \\
\hline $\begin{array}{l}\text { Non- } \\
\text { atopics } 2\end{array}$ & 19 & $15.0 \pm 1.9$ & $4.60 \pm 1.0$ & $4.70 \pm 8.4$ & $125.4 \pm 201.4$ \\
\hline Controls 2 & 20 & $16.4 \pm 4.7$ & $3.76 \pm 0.5$ & $1.98 \pm 1.1$ & $122.4 \pm 105.1$ \\
\hline $\begin{array}{l}\text { Statistical } \\
\text { Significance }\end{array}$ & & $\begin{array}{l}\text { 1-2 n.s. } \\
\text { 1-3 n.s. } \\
\text { 2-3 n.s. }\end{array}$ & $\begin{array}{c}1-2 \text { n.s. } \\
1-3 p<0.05 \\
2-3 p<0.01\end{array}$ & $\begin{array}{c}1-2 \text { n.s. } \\
1-3 p<0.001 \\
2-3 p<0.05\end{array}$ & $\begin{array}{l}\text { 1-2 n.s. } \\
\text { 1-3 n.s. } \\
\text { 2-3 n.s. }\end{array}$ \\
\hline
\end{tabular}

Table 8: This Table demonstrates the differences of serum IL-2, IL-2R and ICAM-1 between atopic, non-atopic asthmatics and healthy blood donors.

Serum concentrations of IL-2, IL-2 R and ICAM-1 in atopic and non atopic asthmatics

\begin{tabular}{|l|c|c|c|c|}
\hline Group & $\mathrm{N}$ & $\begin{array}{c}\mathrm{IL}-2 \\
(\mathrm{pg} / \mathrm{ml})\end{array}$ & $\begin{array}{c}\text { IL-2 R } \\
(\mathrm{pg} / \mathrm{ml})\end{array}$ & $\begin{array}{c}\text { ICAM-1 } \\
(\mathrm{ng} / \mathrm{ml})\end{array}$ \\
\hline Atopics 1 & 29 & $10.0 \pm 0.9$ & $1215.4 \pm 510.4$ & $448.9 \pm 148.1$ \\
\hline $\begin{array}{l}\text { Non- } \\
\text { atopics 2 }\end{array}$ & 19 & $9.8 \pm 0.7$ & $1171.5 \pm 386.2$ & $446.5 \pm 185.6$ \\
\hline Control 3 & 20 & $9.5 \pm 1.1$ & - & $189.0 \pm 42.3$ \\
\hline $\begin{array}{l}\text { Statistical } \\
\text { Significance }\end{array}$ & $\begin{array}{l}1-2 \text { n.s. } \\
1-3 \text { n.s. }\end{array}$ & $1-2$ n.s. & $\begin{array}{c}1-2 \text { n.s. } \\
1-3 \mathrm{p}<0.001 \\
2-3 \mathrm{p}<0.001\end{array}$ \\
\hline
\end{tabular}

\section{Discussion}

It is quite clear, that application of fiberoptic bronchoscopy with endobronchial (eventually transbronchial) biopsy has allowed a direct appraisal and investigation of mucosal cellular events of airways inflammaton in asthmatic patients $(5,22,26)$. However this investigation, being invasive, cannot be repeatedly used in routine clinical practice. Nearly the same is true for the investigation of samples, taken from bronchoalveolar lavage (BAL) fluid. These methods are mainly applied in research studies.

Recently, a method of induced sputum cell counts, using hypertonic saline solution inhalation, has been pro- 
posed as a non invasive alternative to BAL in clinical practice for investigation of various cells, coming from the periphery of the airways, the results being comparable to that of bronchoalveolar lavage (49). Despite its noninvasiveness, technical equipment requirement and longtime duration (45-60 minutes), makes this method less convenient for daily clinical use.

Because of the difficulty in routinely obtaining samples from the lung, there has been considerable interest in potential blood-born markers of airways inflammation. Some changes have been shown in T-lymphocyte activation markers and cytokines in peripheral blood, particulary in more severe asthma. However it is not quite clear what is their relationship to events in the airways $(2,36)$. Bearing this in mind, the evaluation of our measurements will be discussed in the following paragraphs.

\section{Interleukin - 4 (IL - 4)}

Interleukin-4 is not only responsible for B-cells isotype switching in favour of IgE production, but it also may account, at least in part, for selective eosinophil recruitment at sites of allergic tissue reactions. Dr. de Vries (12) had been unable to find circulating IL-4 in patients with very high IgE serum levels, probably because the IL-4 is released locally and acts by cell-to-cell contacts in a paracrine or autocrine way. However, Matsumoto measured higher IL-4 serum levels in atopic asthmatics in comparison with nonatopic subjects, but no significant correlations with $\operatorname{IgE}$ or sFcER II $\left(\mathrm{CD}_{23}\right)$ levels were found (35).

IL-4 serum concentrations in our asthmatic patients were not increased either in severe or mild degrees of the disease in comparison with healthy control subjects. It appears that the measurement of IL-4 in peripheral blood cannot be a useful marker of inflammatory reaction in the asthmatic airways. Interestingly enough, IL-4 serum concentrations were not of discriminatory potency between atopic and nonatopic subjects as could be expected.

\section{Soluble low-affinity FcER II (CD-23)}

Soluble Fc epsilon receptor II is a fragment of FcE RII expressed mainly on B-cells, its expression being poor on normal B-cells. Interleukin-4 enhances this expression while INF-gamma inhibits the effect of IL-4 on FcE RII expression. IgE production and FcE RII expression on B-cells are two closely related events (35). FcE RII is both an autocrine and a paracrine B-cell stimulatory factor and soluble FcE RII ( $s F c E$ RII) may thus possibly be a parameter of B-cell activation.

An increase in sFcE RII in 77 asthmatics was found by Matsumoto, but no difference between atopic and nonatopic subjects was present and no significant relationship to IL-4 and total IgE was shown (35). In Billery\#s work on 48 atopic subjects an elevation in percentage and absolute values of B-cells expressing FcE RII by flow cytometry was measured. Allergics to pollens had an elevation only during the season (6). There was no correlation between $\mathrm{sFcE}$ RII and IgE levels, eosinophilic cationic protein (ECP) or symptom score. According to their view, the upregulation of FcE RII in atopics reflects allergen exposure and cannot serve as a diagnostic marker of atopy out of the exposition period. The evaluation of $\mathrm{CD}_{23}$ isn't useful in monitoring allergic patients because it lacks correlation with clinical symptoms. Similarly, de Amici in 19 adults with allergic asthma bronchiale could not find any correlation between sFcE RII and asthma score (11).

An increase of sFcE RII in 55 atopic asthmatics in comparison with healthy people was found by Rogala, but no relationship to total $\mathrm{IgE}$, to allergen specific $\mathrm{IgE}$ or to $\mathrm{IgG}_{4}$ could be estimated (47).

The results of our measurements of sFcE RII are very similar to the above mentioned data. Moreover, in atopic subjects a significant correlation with IgE was found (Table 9). An increase in sFcE RII may by a marker of immunopathologic events in the airways of asthma patients but the lack of relationship to the disease severity indicates that its measurement is of no importance for the practicing clinician.

\section{Interferon - gamma (INF-gamma)}

Interferon-gamma was discovered in 1957 by Issacs as an antiviral protein, produced by cells infected by viruses (31). Since then, other mechanisms of its action (antiproliferative,immunomodulatory) have been demonstrated. Interferon-gamma is known to antagonize the efect of IL-4 on IgE synthesis in the presence of CD-4 T-cells. The administration of recombinant INF-gamma to patients with hyper-IgE syndrom was followed by a $50 \%$ decrease of the IgE blood level, without influencing other immunoglobulin types (7). Peripheral blood monocytes of atopic asthmatics were shown to produce less INF-gamma, following phytohemaglutinin stimulation. When recombinant INF-gamma was added, the INF-gamma was increased to normal values $(33,39,64)$.

INF-gamma serum levels in asthmatics have shown different results. While in Soliman's work on atopic asthmatics no significant changes of INF-gamma compared to controls were found (52), Kimura was able to demonstrate a significant increase of INF-gamma in severe forms of asthma, in comparison with mild asthmatics (28).

A significant increase of the INF-gamma serum level in both groups of our asthma patients could be evaluated as a T-cell activation marker in the inflammatory process of their airways wall. On the other hand, no difference in its concentration between mild and severe asthmatics makes this finding of no useful purpose for treatment strategy changes in difficult-to-control asthmatics (e.g. recombinant INF-gamma application). 
As shown in table 9, a significant positive correlation between INF-gamma and IL-4 in all asthmatic groups was calculated. The importance of this finding is not clear to us, and no data explaining this relationship in the available literature were found.

Table 9: In this Table, calculated significant correlations between various measured serum parameters in different asthmatic groups are shown.

Significant correlations between different measured serum parameters

\begin{tabular}{|c|c|c|}
\hline \multicolumn{3}{|l|}{ Group } \\
\hline $\begin{array}{l}\text { Difficult-to-control } \\
\text { asthma }\end{array}$ & $\begin{array}{l}\text { IL-4 x INF-gamma } \\
r=0.900 p<0.05\end{array}$ & \\
\hline $\begin{array}{l}\text { Minimal symptomatic } \\
\text { asthma }\end{array}$ & $\begin{array}{l}\text { IL-4 x INF-gamma } \\
\mathrm{r}=0.871 \mathrm{p}<0.01\end{array}$ & \\
\hline \multirow[t]{2}{*}{ Atopics } & $\begin{array}{l}\text { IL-4 x INF-gamma } \\
\mathrm{r}=0.919 \mathrm{p}<0.01\end{array}$ & $\begin{array}{l}\text { sFcERII x IgE } \\
r=0.948 p<0.001\end{array}$ \\
\hline & $\begin{array}{l}\text { IgE x ICAM-1 } \\
r=-0.535 p<0.05\end{array}$ & $\begin{array}{l}\text { IL-2 x ICAM-1 } \\
r=-0.495 p<0.05\end{array}$ \\
\hline Non-atopics & $\begin{array}{l}\text { IL-4 x INF-gamma } \\
\mathrm{r}=0.861 \mathrm{p}<0.001\end{array}$ & \\
\hline
\end{tabular}

\section{Immunoglobulin-E (IgE)}

Immunoglobulin-E was first isolated from serum in 1966 by Ischizaka (8). Its highest concentrations are found in atopic poeple, who are characterized by a persistent IgEmediated response to common environmental allergens $(1,7)$. Atopy, which contributes to diseases such as asthma, eczema and allergic rhinitis, is defined as a disorder of the IgE response to common allergens, such as pollen, animal dander, house dust mites and fungi. These diseases are frequently detected by a raised total IgE serum level, and positive skin tests to common aeroallergens. Despite the high prevalence of atopy in population studies (about 30-40\%), the incidence of manifested allergic disease (asthma bronchiale, rhinitis, eczema) is present in only $5-10 \%$ of them $(8,16,17)$. A number of variables have been shown to affect both IgE serum levels and bronchial hyperresponsiveness. Smoking has been shown to lead to an increase in total IgE serum levels. The effect of age, environmental factors undoubtedly was proven to influence the basal values of IgE $(17,18)$.

The IgE plasma levels in nonatopics are usually normal or only slightly elevated.

The above mentioned findings are in accordance with our results. IgE serum concentrations were highest in the group of severe asthmatics and in patients with atopy. The absence of statistical significance was due to one excessive $\mathrm{IgE}$ value in one patient with severe atopy. This extreme concentration was not false result because repeated measurements were in a similar range. The IgE serum level posi- tively correlated with sFcE RII concentration, while the correlation of IgE with sICAM-1 was found in a significantly negative value $(r=-0,535 \mathrm{P}<0,05)$. No similar estimation for this correlation in the available literature was found.

One of our primary aims for studying these serum parameters in severe asthmatics was the identification of patients characterized by high IL-4, high IgE, high sFcERII and low INF-gamma. The intention was, to treat these patients by administering recombinant INF-gamma to block the influence of IL-4 on IgE switching in B-cell. Unfortunately, not one patient with this laboratory phenotype was estimated. In between, further progress in the therapy of atopic asthmatics has been demonstrated, e.g. by using specific anti-IL-4 or anti-IgE antibodies $(12,14)$.

\section{Interleukin-2 (IL-2) and s IL-2 R}

Interleukin-2 is an essential growth factor for T-cells (28). IL-2 acts in an autocrine fashion to stimulate T-cell proliferation and also serves to regulate immunoglobulin production and the growth of cytotoxic T-lymphocytes and Natural Killer Cells $(1,16)$. Upon activation of the T-lymphocytes by antigens, an increase of the HLA-DR antigen, of the alpha subunit of the IL-2 receptor (CD-25) and of VLA1 are found. IL-2 $\mathrm{R}$ on the T-cell surface is appearing 24 hours after antigen challenge and is present there for several days. Interleukin-2 provides a necessary signal for the transition of the activated T-cells from the G 1 to the s-phase of the cell cycle. During activation, the lymphocytes secrete glycoproteins related to their surface proteins, including the sIL-2 R $(40,50)$.

While the determination of activated T-lymphocytes in peripheral blood provides information only about the immunological situation in this compartment, the determination of sIL-2 R gives an overview of the general situation of the allergic situation of the allergic inflammation in specific organs (50).

Increased plasmatic concentration of sIL-2 $\mathrm{R}$ were found in acute asthmatic attack and its decline correlated with an increase in FEV-1 and a decrease of symptoms following treatment by corticosteroids $(1,2,10,29)$. A segmental allergen provocation test in asthmatics is followed by an enormous increase of sIL-R in BAL fluid $(55,56)$. The concentrations of IL-2 and sIL-2 R were higher in the BAL fluid of symptomatic patients with bronchial asthma than in those of asymptomatic patients (40). Serum s-IL$2 \mathrm{R}$ was elevated even in 77 minimally symptomatic adult asthmatics in comparison with 75 control subjects (35). No difference in sIL-2R levels between atopic and nonatopic subjects could be demonstrated (35). Quite different results were described by Walker (59). In his work, the sIL-2 was significantly elevated only in non-atopic asthmatics.

According to Kips and Midander, no uniform relationship exists between s IL-2R and allergic airways inflammati- 
on as well as between s IL-2R and severity of asthmatic symptoms $(29,36)$.

Our results of serum IL-2 and s IL-2R levels are in accordance with the above cited findings, these parameters not being able either to discriminate between the different severity of asthmatic symptoms or to differentiate atopic and nonatopic asthmatics. Therefore, we don't recommend the measurement of these parameters in the serum of asthmatic patients as an activity marker of allergic airways inflammation.

\section{Intercellular adhesion molecule-1 (ICAM-1)}

The recruitment of leucocytes to sites of inflammation involves a well co-ordinated sequence of events, in which several cell adhesion molecules and chemotactic cytokines play an active role $(21,30)$. Initial low affinity selectin-dependent vascular rolling is followed by leucocyte activation by endothelial-derived chemoattractants (e.g. IL-8, monocyte chemoattractant peptide-1-MCP-1) and a transition to beta-integrin-dependent high affinity leucocyte adherence cytokine-mediated upregulation of the Ig superfamily of adhesion proteins, ICAMs and vascular cell adhesion molecules (VCAMs), leading ultimately to transendothelial migration.

ICAM-1 is a $80-115 \mathrm{kD}$ glycoprotein with a large cell distribution. Its increased secretion is stimulated by various cytokines (e.g. IL-1, TNF-alfa, INF-gamma). ICAM-1 serves as a ligand for beta-2 leucocyte integrins LFA-1 and MAC-1 and enhances adhesion of leucocytes provided with these receptors to the tissue expressing ICAM-1 (30).

Within 6 hours of segmental allergen challenge of the sensitized asthmatic airways, a marked endothelial upregulation of E-selectin and ICAM-1 occurs accompanied by an influx of leucocyte function associated antigen-1 (LFA-1) leucocytes comprising neutrophils and eosinophils (37).

Epithelial cell expression of ICAM-1 in asthmatics has been compared with controls. While Montefort found no difference in ICAM-1 expression between asthmatic and control epithelium (37), Vignola demonstrated that ICAM1 expression was increased in asthmatics and that it correlated with clinical score and lung function (44,54). A soluble form of ICAM-1 (sICAM-1) has been detected in the sera of patients with bronchial asthma $(42,51)$. Its increased concentrations were found both in atopic as well as in non atopic asthmatics. Serum concentrations of sICAM1 were higher during asthma attacks than in the same patients during remission (51). Serum sICAM-1 levels were also lower during treatment with oral prednison $(42,51)$.

On the other hand, biopsies from patients with severe „steroid resistant“ asthma have revealed a marked upregulation of ICAM-1 and VCAM-1 in the absence of allergen exposure and while taking high doses of corticosteroids. According to Holgate, the examination of ICAMs may offer a possible biomarker of asthma activity (21). It has been shown that pretreatment of monkeys with a monoclonal an- tibody specific for ICAM-1 attenuates the eosinophil infiltration and airway responsiveness to inhaled methacholine (58). These studies suggest that ICAM-1 may by pivotal in the pathogenesis of airway hyperresponsiveness and asthma.

Based on the potential importance of cell adhesion molecules in allergic and inflammatory reactions, various approaches are being developed to develop specific antagonists (60). While inhibition of adhesion molecules is an attractive new approach to the treatment of inflammatory disease, there may be potential dangers in inhibiting immune responses, leading to increased infections and increased risk of neoplasia (3).

As far as our measurements of sICAM-1 are concerned, significantly higher levels in both asthmatic groups compared to controls, may be a marker of permanent allergic inflammation in the airways of these patients without relationship to clinical asthma severity. The upregulation of ICAM-1 in our patients was independent of their atopic profile. The significant negative correlation to IL-2 and IgE concentrations is hard to explain.

Because of the lack of differentiation between mild and severe asthmatics, we consider the estimation of sICAM-1 in peripheral blood as an non-sensitive marker of airway inflammation.

\section{Conclusions}

1) The group of difficult-to-control asthmatics cannot be differentiated by a specific cytokine profile in peripheral blood samples from minimally symptomatic patients.

2) Some increased levels of T-and B-cell activity markers (INF-gamma, sFcER II) and of sICAM-1 even in minimally symptomatic asthma patients, point to permanent chronic inflammatory process in their airways.

3) No patient of the difficult-to-control asthma cohort with a laboratory phenotype of high IgE, high sFcER II, low INF-gamma and high IL-4 serum concentration could be found, so as to allow the causative therapy by recombinant interferon-gamma.

4) Despite some interesting results observed in investigations of the above mentioned parameters, we do not consider their estimation in peripheral blood samples of severe asthmatics helpful in therapeutic strategy changes.

\section{References}

1. Agostini C, Semenzato G. Immune response in the lung: basic principles. Lung 1990;168S:1001-12.

2. Barnes I. Evaluating asthma and its treatment: Clinical markers and indicators of efficacy. Eur Respir Rev 1996;6:31-2.

3. Barnes PS. New drugs for asthma. Eur Respir J 1992;5:1126-36.

4. Barnes PS, Holgate ST, Laitinen LA, Pauwels R. Asthma 
mechanisms, determinants of severity and treatment: the role of nedocromil sodium. Clin Experimental Allergy 1995;25:771-87.

5. Beasley R, Burgess C, Crane J et al. Pathology of asthma and its clinical implications. J Allergy Clin Immunol 1993;92:148-54.

6. Billery L, De Franchis G, Plebani M. Fc E RII/CD-23 expression in atopic subjects during natural allergen exposition. J Allergy 1996;51(Suppl. 31): 107.

7. Borish L, Joseph BZ. Inflammation and the allergic response. Med Clin North Am 1992;76:765-87.

8. Burrows B, Martinez FD, Halonen $\mathrm{M}$ et al. Association of asthma with serum IgE levels and skin test reactivity to allergen. N Engl J Med 1985;320:217-77.

9. Ceyhan BB, Sungur M, Turgay C et al. Role of adhesion molecule ICAM-1 in asthma. J Asthma 1995;32:419-27.

10. Corrigan CJ, Hartnell A, Kay AB. T-lymphocyte activation in acute severe asthma. Lancet 1988:1129-33.

11. Corrigan CJ. Elevated interleukin-4 secretion by T-lymphocytes: a feature of atopy or of asthma? N Engl J Med 1985;320:271-77.

12. De Amici M. Serum soluble CD-23 (sCD-23) levels in patients with allergic respiratory disorders. J Allergol 1996;51(Suppl. 31): 108.

13. deVries JE. Cytokines in Allergy. Conversations in Allergy IV. UCB Institute of Allergy, 1994:11-2.

14. Drazen JM, Turino GM. Progress at the interface of inflammation and asthma. Am J Respir Crit Care Med 1995; 152:386-7.

15. Eum SY, Heusser C, Lefort $\mathbf{J}$ et al. Inhibition of bronchial hyperactivity and eosinophil infiltration into the mouse airways by a non-anaphylactic anti-IgE antibody. Eur Respir J 1996;9(Suppl. 23):136pp.

16. Frew AJ. The inflammatory basic of asthma. Eur Respir Rev 1996;6:1-3.

17. Geba GP, Zitnik RJ, Elias JA. Interleukins in the pulmonary inflammatory response. In: Molecular biology of lung disease. Blackwell Scientific Publications: London, 1994:314-43.

18. Geha M. Regulation of IgE. Conversations in Allergy IV. UCB Institute of Allergy, 1994:5-6.

19. Holgate ST. Cellular and mediator mechanisms in asthma. UCB Institute of Allergy, 1992:1-20.

20. Holgate ST, Djukanovič R., Howarth PH. Mucosal inflammation and its clinical consequences. In: Marsh DG, Lockhart A, Holgate S.:The genetics of asthma. Blackwell Scientific Publications:London, 1993:41-57.

21. Holgate ST. Asthma: past, present and future. Eur Respir J 1993;6:1507-20.

22. Holgate ST. The inflammation-repair cycle in asthma: possible new biomarkers of disease activity. Eur Respir Rev, 1996;6:4-10.

23. Howarth PH, Wilson R, Djukanovic R et al. Airway inflammation and atopic asthma: a comparative bronchoscopic investigation. Int Arch Allergy Appl Immunol 1991;94:266-9.
24. Hruškovič I, Kayserová $H$, Čižnár $\mathrm{P}$, Brezina $\mathrm{M}$. Súčasné názory na patofyziológiu bronchiálnej astmy. Detský lekár 1995;2(Suppl.):5-8.

25. Chanarin N, Corne J, Holgate ST. Workshop report. Asthma: basis and management at different ages. Respir Med 1995;89:409-13.

26. Irwing R, Curley FJ, French CL. Difficult-to-control asthma. Contributing factors and outcome of a systematic management protocol. Chest 1993;103:1662-9.

27. Jeffery PK, Wardlav AJ, Nelson FC et al. Bronchial biopsies in asthma: an ultrastructural, quantitative study and correlation with hyperreactivity. Am Rev Respir Dis 1989; 140:1745-53.

28. Kay AB. T-lymphocytes as effector cells in asthma. In: Marsh DG, Lockhart A, Holgate ST. The genetics of asthma. Blackwell Scientific publications:London, 1993:27-32. 29. Kimura G, Takahashi K, Tada S et al. The role of interferon gamma in pathogenesis of bronchial asthma. XIV International Congress of Allergology and Clinical Immunology, Kyoto, Japan, 1991:33.

30. Kips J. Monitoring cellular activity in allergic airway inflammation. ECACI 95, Monduzzi Editore Bologna, 1995:495-502.

31. Krejsek J, Kopecký O, Fixa B. Adhezivní molekuly a imunologie zánětu. Stud Pneumol Phtiseol 1993;53:14955.

32. Krejsek J, Kopecký O, Fixa B. Cytokiny a jejich působení v imunitním systému. Lék Zpr LF UK Hradec Králové 1994;39:17-25.

33. Krejsek J, Kopecký O, Král B. Imunopatogeneze asthma bronchiale. 1. regulační působení T-lymfocytů syntéza IgE. Stud Pneumol Phtiseol 1996;56:214-8.

34. Lack G, Renz Saloga J et al. Nebulized but not parenteral INF-gamma decreases IgE production and normalizes airways in murin model of allergen sensitization. J Immunol 1994;152:2546.

35. Mariani F, Price JF, Kemeny DM. The IgG subclass antibody response to inhalant allergen (D. pteronyssinus) during the first year of life: evidence for early stimulation of the immune system following natural exposure. Clin Exp Allergy 1992;22:29-35.

36. Matsumoto K, Taki F, Miura M et al. Serum levels of soluble IL-2R, IL-4 and soluble Fc E RII in adult bronchial asthma. Chest 1994;105:681-6.

37. Midander J. Clinical documentation of inflammation markers in asthma. Clin Exp Allergy 1993;23(Suppl.):13-4. 38. Montefort S, Lai CK, Kapahi P et al. Circulating adhesion molecules in asthma. Am J Respir Crit Care Med 1994;149:1149-52.

39. O’Byrne PM. The natural history of asthma. Eur Respir Rev 1996;6:23-6.

40. Papadopoulos NG et al. Restorement of defective INFgamma production in PBMC of atopic patients by addition of INF-gamma. J Allergy 1996;51(Suppl. 31):18.

41. Park ChS, Lee SM, Chung SW et al. Interleukin-2 and soluble interleukin-2 receptor in bronchoalveolar lavage flu- 
id from patients with bronchial asthma. Chest 1994; 106:400-6

42. Pauwels R. Asthma: managing the underlying disease. Eur Respir Rev 1994;4:291-4.

43. Pavlovičová E, Michaličková J, Ondrišová $\mathrm{M}$ et al. Hladiny cirkulucej intercelulárnej adhezívnej molekuly s ICAM-1 u pacientov s bronchiálnou astmou. Stud Pneumol Phtiseol 1995;55:380-5.

44. Punnonen J, Carballido JM, Aversa G et al. Inhibition of human IgE synthesis by an IL-4/IL-13 receptor antagonist in vitro and in vivo. ECACI, 1995:29-33.

45. Reaburn D, Webber SE. Proinflammatory potential of the airway epithelium in bronchial asthma. Eur Respir J 1994; 7:2226-33.

46. Ricci M. IL-4 a key cytokine in atopy. Clin Exp Allergy 1994;24:801-12.

47. Ricci M. Allergic inflammation in asthma. UCB Institute of Allergy, 1994:15-7.

48. Rogalla B, Taszakowski W. Serum level of soluble CD23 (sCD-23) in pollinotic and house dust mite sensitive patients undergoing specific immunotherapy. Eur Respir J 1996;9(Suppl. 23):89pp.

49. Romagnani S. Regulation of human IgE synthesis and its deregulation in atopic subjects. In: The Genetics of Asthma. Blackwell Scientifique Publications, 1993:163-76.

50. Ronchi MC, Piragino C, Rosi E et al. Role of sputum differential cell count in detecting airway inflammation in patients with chronic bronchial asthma or COPD. Thorax 1996;51:1000-4.

51. Sanchez A. Changes in the receptors of activation in lymphocytes $\mathrm{T}$ in peripheral blood and in serum (sIL-2R) after allergen challenge. J Allergy 1996;51(Suppl. 31):100.

52. Shiota Y, Wilson JG, Marukawa M. Soluble intercellular adhesion molecule 1 (ICAM-1) in sera of bronchial asthmatics. Chest 1996;109:94-9.

53. Soliman MA, El-Hanna A, El-Hadidi A et al. Soluble interleukin-2 receptor, interleukin-4 and interferon gamma in bronchoalveolar lavage fluid of asthmatic patients. J Allergy 1996;51(Suppl. 31):292.

54. Sont JK, Van Krieken JM, Evertse ChE et al. Relationship between the inflammatory infiltrate in bronchial biopsy specimens and clinical severity of asthma in patients treated with inhaled steroids. Thorax 1996;51:496502.
55. Vignola AM, Campbell AM, Chanel P et al. HLA-DR and ICAM-1 expression in bronchial epithelial cells in asthma and chronic bronchitis. Am Rev Respir Dis 1993;148:689-94.

56. Virchow JCJr, Walker C, Hafner D et al. Cytokine networking in asthmatic inflammation. Its role in lymphocyte and eosinophile activation. Eur Respir J 1993;6(S 17):514. 57. Virchow JCJr, Kroegel C, Walker C, Matthys H. Cellular and immunological markers of allergic and intrinsic bronchial asthma. Lung 1994;172:313-34.

58. Vondra V. Reisová M. Prevalence bronchiálního astmatu stoupá, mortalita kolísá. Cas Lek Cesk 1996;135:471-6. 59. Wagner CD, Rothlein R, Clarke CC et al. Inhaled antiICAM-1 reduces antigen-induced airway hyperresponsiveness in monkeys. (Abstract). Am Rev Respir Dis 1991;143:A418.

60. Walker C, Bode E, Boer L et al. Allergic and nonallergic asthmatics have distinct patterns of $\mathrm{T}$ cell activation and cytokine production in peripheral blood and bronchoalveolar lavage. Am Rev Respir Dis 1992;146:109-15.

61. Wein M, Bochner BS. Adhesion molecule antagonists: future therapies for allergic diseases ? Eur Respir J 1993;6:1239-42.

62. Wierenga EA, Snoek M, Bos JD et al. Comparison of diversity of house dust mite-specific T-lymphocyte clones from atopic and nonatopic donors. Eur J Immunol 1990;20:1519-26.

63. Wierenga EA, Snoek M, DeGroot $\mathrm{C}$ et al. Evidence for compartmentalization of functional subsets of CD-4+ T lymphocytes in atopic patients. J Immunol 1990;144: 4651-60.

64. Wilkinson J, Holgate ST. Candidate gene loci in asthmatic and allergic inflammation. Thorax 1996;51:3-8.

65. Zervaki E, Papadopoulos NG, Androani E et al. INFgamma and IL-4 production in atopic children. J Allergy 1996;51(Suppl. 31):148.

Submitted May 1997.

Accepted June 1997.

Prof. MUDr. Bohuslav Král, CSc., IInd Department of Medicine, Charles University, Faculty of Medicine, 50005 Hradec Králové, Czech Republic. 